\title{
Article \\ Impact of Watermelon Rind and Sea Buckthorn Meal on Performance, Blood Parameters, and Gut Microbiota and Morphology in Laying Hens
}

\author{
Tatiana Dumitra Panaite ${ }^{1,+} \mathbb{D}$, Petru Alexandru Vlaicu ${ }^{1, *,+} \mathbb{D}$, Mihaela Saracila ${ }^{1,+}$, Ana Cismileanu ${ }^{1}$, \\ Iulia Varzaru ${ }^{1}$, Sorina Nicoleta Voicu ${ }^{2}$ D and Anca Hermenean ${ }^{3}$ (D) \\ 1 Department of Chemistry and Animal Nutrition Physiology, \\ National Research and Development Institute for Animal Nutrition and Biology, 077015 Balotesti, Romania; \\ tatiana.panaite@ibna.ro (T.D.P.); mihaela.saracila@ibna.ro (M.S.); ana.cismileanu@ibna.ro (A.C.); \\ iulia.varzaru@ibna.ro (I.V.) \\ 2 Department of Biochemistry and Molecular Biology, Faculty of Biology, University of Bucharest, \\ 050095 Bucharest, Romania; sorina.voicu@unibuc.ro \\ 3 Department of Experimental and Applied Biology, Aurel Ardelean Institute of Life Sciences, \\ Vasile Goldis Western University of Arad, 310414 Arad, Romania; anca.hermenean@gmail.com \\ * Correspondence: alexandru.vlaicu@ibna.ro \\ + These authors contributed equally to this work.
}

check for

updates

Citation: Panaite, T.D.; Vlaicu, P.A.;

Saracila, M.; Cismileanu, A.; Varzaru,

I.; Voicu, S.N.; Hermenean, A. Impact of Watermelon Rind and Sea Buckthorn Meal on Performance,

Blood Parameters, and Gut

Microbiota and Morphology in

Laying Hens. Agriculture 2022, 12,

177. https://doi.org/10.3390/

agriculture12020177

Academic Editor: Alenka Levart

Received: 17 December 2021

Accepted: 25 January 2022

Published: 26 January 2022

Publisher's Note: MDPI stays neutral with regard to jurisdictional claims in published maps and institutional affiliations.

Copyright: (C) 2022 by the authors. Licensee MDPI, Basel, Switzerland. This article is an open access article distributed under the terms and conditions of the Creative Commons Attribution (CC BY) license (https:// creativecommons.org/licenses/by/ $4.0 /)$.

\begin{abstract}
Natural ingredients from fruits and fruit-derived by-products have gained special interest as dietary supplements in poultry because of their health-promoting effects. The present work aims to evaluate the impact of the dietary inclusion of watermelon rind and sea buckthorn meal on performances, blood parameters, and gut microbiota and morphology of laying hens. A 4-week trial was conducted on 90 Tetra SL layers (32 weeks old), assigned to three dietary treatments (C, E1, and E2). The $C$ group hens were fed a basal diet based on corn-soybean meal. The experimental diets included $10 \mathrm{~g}$ of watermelon rind $/ \mathrm{kg}$ fed (E1) and $20 \mathrm{~g}$ of sea buckthorn meal $/ \mathrm{kg}$ fed (E2). During the feeding trial, we monitored the performances. Blood samples, intestinal tissue, and intestinal content were collected to assess the effect of dietary ingredients on health status, digestive enzyme activity, intestinal morphology, and gut microbiota characterization. From the blood samples, cholesterol and triglycerides significantly $(p<0.05)$ decreased in E1 and E2 compared with the C group. Dietary watermelon rind and sea buckthorn meal positively impacted villus height. Maltase and invertase activity increased only in the duodenum of the E2 group, while alpha-amylase decreased in the duodenum and jejunum of both E1 and E2 groups. The two supplements tested triggered Firmicutes and Lactobacillus spp. multiplication, while reducing harmful bacteria such as Bacteroidetes and Enterobacteriaceae. The study provides the first evidence that the dietary inclusion of watermelon rind and sea buckthorn meal can be used in laying hens' diets with a beneficial impact on hens' biochemical parameters, gut microbiota, and gut morphology.
\end{abstract}

Keywords: laying hen; performance; sea buckthorn meal; watermelon rind; animal health; microbiota; intestinal morphology; intestinal health

\section{Introduction}

Intestinal health is a crucial parameter in ensuring the health of birds and the optimal use of nutrients because of its various functions, namely the digestion and absorption of nutrients, the secretion of mucins and immunoglobulins, and selective protection against pathogens [1]. This topic has gained even more interest in poultry production because of increasing demands for economic efficiency, animal welfare, food safety, reducing environmental impact, and banning or avoiding the use of antibiotics as a growth promoter [2,3]. Excepting the crucial role of the intestine in nutrient absorption, the digestive enzymes are of great importance to catalase the splitting of proteins, carbohydrates, lipids, and other 
nutrients for more digestible molecules [4]. The link between intestinal health and nutrition is indisputable, covering gut development, microflora, and microstructure. Dietary factors, such as composition, digestibility, and feeding methods, could influence intestinal integrity and the ecosystem [5]. Currently, there is a growing interest among researchers about how some feeds can help maintain animal health beyond their traditional nutritive value [6]. The antibiotic treatment used for bacterial and other animals' diseases is prohibited because of the residues it leaves in animal products (e.g., eggs, meat, milk) and its impacts on human health. It is, therefore, necessary to find natural alternatives, especially using natural ingredients from plant and plant-derived by-products [7]. Feeding poultry various plant/by-products to enhance intestinal health and thus improve performance is one strategy that has attracted prominent attention [8]. Natural sources such as meals, plants, fruits, essential oils, and different extracts and mixtures are important sources of carbohydrates, proteins, lipids, amino acids, and other valuable nutrients [9]. Many of them have been tested previously in other poultry trials with positive effects on health [10-12]. Moreover, many of these dietary supplements promote intestinal health and integrity by being rich in fibers and amino acids, which are major nutrients for maintaining intestinal mucosal integrity and supporting the growth of microorganisms in the gut [13].

Watermelon (Citrullus lanatus) is a major fruit widely distributed in the tropics. It contains about $6 \%$ sugar and $91 \%$ water by weight [14]. The pulp (edible for human consumption) constitutes approximately $68 \%$ of the total weight, while the rind and seed make up approximately $32 \%$, of which $2 \%$ is seeds [15]. Like many other fruits, it is a source of vitamin C, serving as a good source of phytochemicals [16], with a significant amount of citrulline. Citrullus lanatus rind possesses significant amounts of moisture (10.61\%), ash $(13.09 \%)$, crude protein $(11.17 \%)$, fat $(2.44 \%)$, and carbohydrates (56\%) [17]. Watermelon rinds are edible, being rich in many hidden nutrients, but because of their unappealing flavor, most people avoid eating them [18]. For this reason, watermelon rind has become a good candidate for poultry feeding, with a beneficial effect on health.

Sea buckthorn (Hippophae rhamnoides), an ancient crop with modern virtues, has been utilized not only for feeding purposes but also as a traditional medicine to prevent or treat various diseases, such as inflammation, gastric ulcers, and dermatological disorders [19-21]. Sea buckthorn berries consist of pulp (68\%), seed (23\%), and peel (7.75\%) [22], containing many bioactive compounds such as antioxidants, flavonoids, and polyphenols [23,24]. Due to the nutritional and functional properties of sea buckthorn, it has gained popularity all over the world, which makes this fruit residue (meal) a good candidate as a dietary feed because of its high antibacterial and antiviral effects.

Therefore, the objective of the current study was to investigate the impact of watermelon rind and sea buckthorn meal on performances, blood parameters, intestinal health, and gut morphology changes in laying hens.

\section{Materials and Methods}

\subsection{Plant Materials Preparation}

Watermelon fruits (Citrullus lanatus) were purchased from the agri-food market in the southern region of Romania. After removing the flesh, the obtained rinds were cut with a stainless-steel knife into small pieces with lengths of $1 \mathrm{~cm}$ and thicknesses of $0.8 \mathrm{~cm}$ for their faster drying. Before drying, watermelon peels were weighed using an electronic balance (Kern Precision, Germany), whereupon they were placed in drying trays and then in a BMT drying oven, an ECO CELL Blueline Comfort (Nuremberg, Germany), at a constant temperature of $65^{\circ} \mathrm{C}$ for $48 \mathrm{~h}$. After drying ( $48 \mathrm{~h}$ in the oven), the rind (shell) was weighed to determine the initial moisture content, then milled to a powder in a laboratory hammer mill with a $1 \mathrm{~mm}$ screen. Sea buckthorn meal was purchased from a commercial producer located in the southern part of Romania (2-EProd SRL, Teleorman). The meal was obtained by cold pressing (ROC technology) of sea buckthorn fruits and mechanical oil extraction, through high-speed extraction (HSE) rooms. By optimizing the cold pressing parameters (temperature, pressure, and humidity), sea buckthorn meal consisting of cellulose and 
protein parts of pressed fruits and obtained at a temperature below $80^{\circ} \mathrm{C}$, has an important content of residual oil rich in nutrients. After drying, the sea buckthorn meal was stored at room temperature $\left(18-22^{\circ} \mathrm{C}\right)$ until further analysis. Furthermore, the watermelon rind powder and sea buckthorn meal were analyzed for their chemical composition (dry matter, crude protein, and amino acids), determined according to standard methods; the metabolizable energy was calculated using the equation by Janssen, [25] and the in vitro protein digestibility using the method proposed by Boisen and Fernandez [26]. All assays were performed in triplicate.

\subsection{Birds and Diets}

The 4-week trial was conducted on 90 Tetra SL layers (aged 32 weeks), homogeneously assigned to three dietary treatments (C, E1, and E2) and housed in an experimental hall equipped with Big Dutchman digestibility cages, placed on three tier levels ( 3 treatments $\times 15$ replicates $\times 2$ birds per cage). The light regimen was set according to the Tetra SL hybrid guidebook (16 h light $/ 8 \mathrm{~h}$ darkness), with $23.1 \pm 1.0^{\circ} \mathrm{C}$ average temperature/period, $66.4 \pm 5.7 \%$ humidity and $1.7 \pm 0.1 \%$ ventilation per layer. The laying hens had free access to feed and water. The control diet (C), based on corn-soybean meal, had $2800 \mathrm{kcal} / \mathrm{kg}$ metabolizable energy and $178 \mathrm{~g}$ crude protein $/ \mathrm{kg}$ of feed and was the same for all three groups (Table 1). Unlike the $\mathrm{C}$ diet, the experimental diets included $10 \mathrm{~g}$ of watermelon rind $/ \mathrm{kg}$ fed (E1) and $20 \mathrm{~g}$ of sea buckthorn meal $/ \mathrm{kg}$ fed (E2). All diets were isonitrogenous and isoenergetic to provide the same level of essential amino acids (lysine, methionine, and cystine). The high concentration of crude fiber in watermelon rind and sea buckthorn meal limits their usage in higher dosages in poultry nutrition and, for that reason, we considered the optimum level of 10 and $20 \mathrm{~g} / \mathrm{kg}$ diet of these ingredients. Diet formulations were developed with dedicated software (Hybrimin Futter 5) in agreement with the feeding requirements of laying hens as given by the NRC [27]. Throughout the experimental period, bodyweight (BW, g/hen), average daily feed intake (ADFI, g/day/hen), feed conversion ratio ( $\mathrm{kg}$ feed/ $\mathrm{kg}$ eggs), egg weight (g), and viability (\%) were monitored. Bodyweight was measured at the beginning and end of the trial. To calculate these data, the cage was considered the experimental unit. Throughout the trial period, no medical treatment was applied to the hens.

\subsection{Sample Collection of Blood, Intestinal Content, and Intestinal Segments}

Before slaughter, 18 birds were randomly selected (six birds/group) for blood sample collection (two samples/bird) at the end of the trial, according to Romanian legislation (Law 206/2004, ordinance 28/31.08.2011). For biochemical determination, approximately $3 \mathrm{~mL}$ of venous blood samples were aseptically collected into $9 \mathrm{~mL}$ plain plastic tubes (anticoagulant-free) containing $14.3 \mathrm{U} / \mathrm{mL}$ of lithium heparin and a gel for plasma separation (Vacutest, Arzergrande, Italy). Serum was separated after centrifugation. The blood samples for hematological determinations were collected into a vacutainer tube containing ethylene diamine tetra-acetic acid (EDTA) heparin anticoagulant. After blood sampling, the same six birds from each group were slaughtered by sectioning the jugular vein and carotid artery, followed by 2 min exsanguination period, according to Romanian Law 43/2014 for the handling and protection of animals used for experimental purposes (Directive 2010/63/EU). The body cavity was immediately opened to collect samples from the duodenum, jejunum, and caecal content, aseptically in sterilized plastic tubes. The samples were preserved at $-20^{\circ} \mathrm{C}$ until light microscopy examination and determination of digestive enzymes and bacteriological analyses. Furthermore, to determine the intestinal morphometry (intestinal villus depth and crypt) from the small intestine of the hens, $3 \mathrm{~cm}$ lengths from two intestinal segments (duodenum and jejunum) were immediately collected from the intestinal lumen. After the samples were washed in $100 \mathrm{~g} / \mathrm{L}$ buffer formalin phosphate solution to remove intestinal contents, they were processed according to standardized histological techniques for paraffin inclusion as follows: formaldehyde fixation (40 g/L buffered solutions), dehydration in successive alcohol baths, and paraffin inclusion. 
Furthermore, after partial fixation $(24 \mathrm{~h})$ in $100 \mathrm{~g} / \mathrm{L}$ formaldehyde buffered solution, the samples were modelled by cutting tissue fragments with a thickness of $3 \mathrm{~mm}$. For a quick and correct fixation, the sectioned fragments were again immersed in a formaldehyde solution of the same concentration and left for another $24 \mathrm{~h}$ at room temperature. Subsequently, the samples were transferred to successive baths of ethyl and butyl alcohol of various concentrations for dehydration, clarified in toluene, and included in paraffin baths at $58{ }^{\circ} \mathrm{C}$.

Table 1. Diet formulation and chemical composition of the diets.

\begin{tabular}{|c|c|c|c|}
\hline \multirow{2}{*}{ Ingredients (g/kg) } & \multicolumn{3}{|c|}{ Dietary Treatments ${ }^{1}$} \\
\hline & $\mathrm{C}$ & E1 & E2 \\
\hline Corn & 300.0 & 290.0 & 280.0 \\
\hline Watermelon rind & - & 10.0 & - \\
\hline Sea buckthorn meal & - & - & 20.0 \\
\hline Wheat & 314.6 & 314.6 & 314.6 \\
\hline Gluten & 40.0 & 40.0 & 40.0 \\
\hline Soybean meal & 212.0 & 212.0 & 212.0 \\
\hline Sunflower oil & 14.6 & 14.6 & 14.6 \\
\hline L-lysine & 0.6 & 0.6 & 0.6 \\
\hline DL-methionine & 1.3 & 1.3 & 1.3 \\
\hline Calcium carbonate & 87.8 & 87.8 & 87.8 \\
\hline Monocalcium phosphate & 14.6 & 14.6 & 14.6 \\
\hline Salt & 4.0 & 4.0 & 4.0 \\
\hline Choline & 0.5 & 0.5 & 0.5 \\
\hline Premix ${ }^{2}$ & 10.0 & 10.0 & 10.0 \\
\hline \multicolumn{4}{|c|}{ Metabolizable energy and amino acid content (calculated) } \\
\hline Metabolizable energy, kcal/kg & 2825.73 & 2813.50 & 2817.39 \\
\hline Lysine, \% & 0.94 & 0.94 & 0.95 \\
\hline Methionine, \% & 0.43 & 0.43 & 0.43 \\
\hline Methionine +cysteine, $\%$ & 0.75 & 0.75 & 0.75 \\
\hline Threonine, $\%$ & 0.68 & 0.68 & 0.68 \\
\hline Tryptophan, \% & 0.20 & 0.20 & 0.20 \\
\hline Arginine, $\%$ & 1.04 & 1.04 & 1.04 \\
\hline \multicolumn{4}{|c|}{ Feed composition (analyzed) } \\
\hline Dry matter, \% & 90.29 & 89.98 & 90.22 \\
\hline Crude protein, $\%$ & 18.90 & 18.52 & 18.92 \\
\hline Crude fat, \% & 2.83 & 2.92 & 2.99 \\
\hline Crude fiber, $\%$ & 4.06 & 3.88 & 4.00 \\
\hline
\end{tabular}

${ }^{1} \mathrm{C}, \mathrm{E} 1, \mathrm{E} 2$ represent a corn-soybean meal basal diet (control); or basal diets containing 1\% watermelon rind powder (E1); or basal diets containing $2 \%$ sea buckthorn meal (E2). ${ }^{2}$ Supplied per kilogram of diet: vitamin A $13500 \mathrm{IU} / \mathrm{kg}$; vitamin D3, $3000 \mathrm{IU} / \mathrm{kg}$; vitamin E, $27 \mathrm{IU} / \mathrm{kg}$; vitamin K, $2 \mathrm{mg} / \mathrm{kg}$; vitamin B1, $2 \mathrm{mg} / \mathrm{kg}$; vitamin $\mathrm{B} 2,4.80 \mathrm{mg} / \mathrm{kg}$; pantothenic acid, $14.85 \mathrm{mg} / \mathrm{kg}$; nicotinic acid, $27 \mathrm{mg} / \mathrm{kg}$; vitamin B6, $3 \mathrm{mg} / \mathrm{kg}$; vitamin B7, $0.04 \mathrm{mg} / \mathrm{kg}$; vitamin B9, $1 \mathrm{mg} / \mathrm{kg}$; vitamin B12, $0.018 \mathrm{mg} / \mathrm{kg}$; vitamin C, $25 \mathrm{mg} / \mathrm{kg}$; manganese, $71.90 \mathrm{mg} / \mathrm{kg}$; iron, $60 \mathrm{mg} / \mathrm{kg}$; copper, $6 \mathrm{mg} / \mathrm{kg}$; zinc, $60 \mathrm{mg} / \mathrm{kg}$; cobalt, $0.50 \mathrm{mg} / \mathrm{kg}$; iodine, $1.14 \mathrm{mg} / \mathrm{kg}$; selenium, $0.18 \mathrm{mg} / \mathrm{kg}$.

\subsection{Determination of Proximate Chemical Composition and In Vitro Protein Digestibility}

Proximate chemical composition of dietary supplements and feeds were analyzed for dry matter (DM), crude protein (CP), ether extract (EE), and crude fiber (CF) according to AOAC [28] methods.

The in vitro protein digestibility $(\mathrm{dCP})$ was determined by the multienzyme method proposed by Boisen and Fernandez [26], applied with modifications for working with a Daisy Incubator (Ankom), by using F57 bags with feed samples and their incubation in 2 liter jars. The nitrogen content of the feed sample was determined according to the Falade et al. [29] method. 


\subsection{Determination of Amino Acid Concentration}

The amino acid concentration in the watermelon rind powder and sea buckthorn meal was determined by high-performance liquid chromatography (HPLC) after sample derivation with ortho-phthalaldehyde (OPA) reagent and detection at $338 \mathrm{~nm}$, using chromatographic HPLC Surveyor Plus Thermo Electron equipment (Waltham, MA, USA) and a HyperSil BDS C18 column (Thermo Electron, Waltham, MA, USA) with silica, dimensions $250 \times 4.6 \mathrm{~mm}$, particle size $5 \mu \mathrm{m}$, with reverse phase, as described previously by Varzaru et al. [30].

\subsection{Determination of Plasma Hematological and Biochemical Parameters}

The biochemical parameters (cholesterol, triglycerides, glucose, alanine aminotransferase, phosphorus, albumin, magnesium, and total protein) analysis was performed on an automatic BS-130 chemistry analyzer (Bio-Medical Electronics Co., Ltd., Shenzhen, China). For that, blood samples were centrifugated at $3000 \times g$ in a refrigerated centrifuge (Eppendorf Centrifuge 5430R; Hamburg, Germany) for $25 \mathrm{~min}$ at $4{ }^{\circ} \mathrm{C}$ to obtain the serum, which was afterwards carefully transferred to plastic vials and stored at $-20{ }^{\circ} \mathrm{C}$ pending further analysis. Hematologic parameters (hemoglobin, HGB; mean corpuscular volume, $\mathrm{MCV}$; mean corpuscular hemoglobin, $\mathrm{MCH}$; hematocrit, HCT; white blood cell, WBC; lymphocytes, LYM; red blood cell, RBC; eosinophils granulocytes, EOS; monocytes, MON; and basophils granulocytes, BAS) were determined using ADVIA 2120i-Siemens, with an automat analyzer of reference for veterinary hematology, based on flow cytometry, with peroxidase reaction and laser detection.

\subsection{Light Microscopy Examination}

Samples from the intestinal wall of the distal portion of the duodenum and jejunum were collected and fixed in the phosphate-buffered paraformaldehyde (conc. $40 \mathrm{~g} / \mathrm{L}$ ), embedded in paraffin (Tissue Tek Sakura). Thereafter, the sections were cut at $4 \mu \mathrm{m}$ using a Microtec Cut 4055 microtome. The sections thus obtained were displayed on histological slides and stained with hematoxylin and eosin, a classic method for differentiating cell types, and subsequently fixed with Canadian balm. The intestinal segments were examined using an optical microscope (Olympus BX43, Tokyo, Japan) equipped with a camera (30 XC Olympus, Tokyo, Japan) for capturing images, using $\times 4, \times 10, \times 20, \times 40$, and $\times 100$ lenses in succession. The measurements were performed for each sample, respectively the depth of intestinal villi, for six intact villi-crypt from each segment (duodenum and jejunum), using Olympus Cell Dimension software. The length of the intestinal villi was considered the distance between the apical region and the base of the villi. The depth of an intestinal crypt was considered the distance between the base of the intestinal villi and the base of the crypt.

\subsection{Determination of Digestive Enzymes Activities}

Maltase (EC 3.2.1.20) and Invertase (EC 3.2.1.26) activities were performed according to the method previously described by Popescu et al. [31]. Alpha-amylase (EC 3.2.1.1) activity was measured by the method of Bernfeld [32] based on the reduction of reducing groups liberated from starch with 3,5-dinitrosalicylic acid (DNS). The absorbance was determined under standard conditions at $546 \mathrm{~nm}$. One unit of amylase activity (enzymatic units, $\mathrm{U} / \mathrm{mg}$ ) was defined as the amount of enzyme that released $1 \mu$ mole of reducing sugars as maltose in one minute at $25^{\circ} \mathrm{C}$ per milligram of protein. Trypsin (EC 3.4.21.4) activity was determined according to the method described by Hummel [33] based on the use of N-p-Tosyl-L-arginine methyl ester hydrochloride (TAME) as the substrate for reacting with trypsin. The absorbance was measured at $247 \mathrm{~nm}$ for $10 \mathrm{~min}$ at $25^{\circ} \mathrm{C}$ to determine the amount of enzyme that hydrolyzes $1.0 \mu \mathrm{mol}$ of TAME in one minute per $\mathrm{mg}$ of protein $(\mathrm{U} / \mathrm{mg})$. The Bradford method was performed to determine the total protein concentration. Bovine serum albumin (BSA) was used as a standard. 


\subsection{Microbiota Characterization}

Cecal samples were collected from each experimental batch ( $n=6$ animals/group) and microbial DNA isolation was done using a commercial kit (All Prep Power Viral DNA/RNA Kit, Qiagen) following the manufacturer's instructions as follows: $250 \mathrm{mg}$ of cecal content were treated with a cell lysis matrix (Power Bead Tubes, Glass $0.1 \mathrm{~mm}$ ) enzyme digestion for the isolation of nucleic acids, followed by spin column purification. The concentration and purity of the microbial AND were quantified using a Qubit4 fluorometer and a Qubit Broad range DNA kit (Applied Biosystems, Waltham, MA, USA). The concentration of all DNA samples was adjusted to $3 \mathrm{ng} / \mu \mathrm{L}$ in sterile nuclease-free water. The relative abundance of microorganisms in cecal DNA was quantified in real time-PCR using an Applied Biosystems ViiA7 instrument. The total number of bacteria in the samples was quantified with universal primers for $16 \mathrm{~S}$ rDNA, as presented in Table 2. Real-time PCR reactions were done using the SYBR Green Master Mix (Applied Biosystems) and specific primers for different taxa. Each PCR reaction included $200 \mathrm{nM}$ of forward and reverse primers, $9 \mathrm{ng}$ of DNA. Samples were incubated at $95^{\circ} \mathrm{C}$ for $5 \mathrm{~min}$ and then amplified by 40 cycles in three steps at $95^{\circ} \mathrm{C}$ for $10 \mathrm{~s}, 60^{\circ} \mathrm{C}$ for $30 \mathrm{~s}$ and $72{ }^{\circ} \mathrm{C}$ for $1 \mathrm{~s}$.

Table 2. Primer sequences used for microbiota characterization.

\begin{tabular}{cc}
\hline Taxonomic Target & Primer Sequence \\
\hline Firmicutes & Firm934F GGAGCATGTGGTTTAATTCGAAGCA \\
& Firm 1060R AGCTGACGACAACCATGCAC \\
Bacteroides & Fwd CCT ACG ATG GAT AGG GGT T \\
& Rev CAC GCT ACT TGG CTG GTT CAG \\
Enterobacteriaceae & Uni515F GTG CCA GCM GCC GCG GTAA \\
& Ent826R GCC TCA AGG GCA CAA CCT CCA AG \\
Lactobacilli & LabF362 ACG AGT AGG GAA ATC TTC CA \\
& LabR677 CAC CGC TAC ACA TGG AG \\
\hline
\end{tabular}

\subsection{Statistical Analysis}

All data were subjected to a one-way ANOVA method with Tuckey as a post hoc test. The differences between the groups regarding hematological and biochemical parameters, performance, and intestinal morphology (villi length, crypt depth and villi length: crypt depth ratio) were analyzed using a one-way ANOVA using IBM SPSS Statistics (version 27.0 for windows, SPSS Inc., Chicago, IL, USA) according to the following model:

$$
Y i j=\mu+T i+e i j
$$

where Yij is the mean of the jth observation of the ith treatment, $\mu$ is the overall mean of the samples, Ti is the effect of the ith treatment, and eij is the effect of the error.

The same program was used for Pearson's correlation analysis to test the association between performance parameters (ADFI, BW, FCR), digestibility of nutrients (dCP), intestinal microbiota, and histology of the duodenum and jejunum of the laying hens across the dietary groups. The graphs for digestive enzyme activities and microbiota characterization were statistically performed using GraphPad Prism 3.03 software (GraphPad Software, La Jolla, CA, USA). Values were determined to be significant when ${ }^{*} p<0.05,{ }^{* *} p<0.001$, or by different letters indicating significant difference between groups $(p<0.05)$.

\section{Results}

\subsection{Chemical Composition of Dietary Supplements}

The chemical composition and amino acid (AA) content of the studied supplements are presented in Table 3. Comparing the two dietary supplements, we observed that sea buckthorn meal had higher crude protein $(\mathrm{CP})$, gross energy $(\mathrm{GE})$, and metabolizable energy (ME) content compared to watermelon rind. On the other hand, the highest nitrogen digestibility coefficient (NDC) of in vitro protein degradability was determined in the 
watermelon sample. From the total AA, glutamate, arginine, aspartate, valine, alanine, leucine, lysine, and threonine were the most representative in watermelon rind, while in the sea buckthorn meal, glutamate was followed by aspartate, arginine, leucine, serine, phenylalanine, lysine, and threonine. Nevertheless, the ratio between the essential (AAE) and non-essential amino acids (AANE) was similar between the two studied supplements (1.290 vs. $1.283 \%)$.

Table 3. Chemical composition of watermelon rind powder and sea buckthorn meal.

\begin{tabular}{|c|c|c|}
\hline Specification & Watermelon Rind & Sea Buckthorn Meal \\
\hline \multicolumn{3}{|c|}{ Chemical composition * } \\
\hline Dry matter, $\mathrm{g} / \mathrm{kg}$ & $847.9 \pm 33.5$ & $914.3 \pm 9.7$ \\
\hline Crude protein, $\mathrm{g} / \mathrm{kg}$ & $95.6 \pm 0.8$ & $145.1 \pm 10.7$ \\
\hline Crude fat, $\mathrm{g} / \mathrm{kg}$ & $8.2 \pm 1.2$ & $177.2 \pm 11.4$ \\
\hline Crude fiber, $\mathrm{g} / \mathrm{kg}$ & $168.4 \pm 7.3$ & $205.2 \pm 11.7$ \\
\hline Gross energy, kcal/100 g & $355.88 \pm 0.11$ & $511.26 \pm 0.51$ \\
\hline Metabolizable energy, kcal/100 g & $215.46 \pm 0.25$ & $292.29 \pm 0.33$ \\
\hline Nitrogen digestibility coefficient, $\mathrm{g} / \mathrm{kg}$ & $538.2 \pm 19.8$ & $382.9 \pm 3.2$ \\
\hline \multicolumn{3}{|c|}{ Amino acids content, $\mathrm{g} / \mathrm{kg}$ * } \\
\hline \multicolumn{3}{|c|}{ Essential amino acids } \\
\hline Isoleucine & $3.21 \pm 0.30$ & $7.37 \pm 0.15$ \\
\hline Leucine & $4.68 \pm 0.75$ & $13.04 \pm 0.98$ \\
\hline Lysine & $3.58 \pm 0.73$ & $7.80 \pm 0.24$ \\
\hline \multicolumn{3}{|c|}{ Aromatic amino acids } \\
\hline Tyrosine & $3.62 \pm 0.30$ & $4.65 \pm 0.02$ \\
\hline Phenylalanine & $4.33 \pm 0.13$ & $8.55 \pm 0.98$ \\
\hline \multicolumn{3}{|c|}{ Sulphur amino acids } \\
\hline Methionine & $1.75 \pm 0.10$ & $4.10 \pm 0.33$ \\
\hline Cystine & $0.57 \pm 0.04$ & $1.22 \pm 0.17$ \\
\hline Threonine & $2.67 \pm 0.18$ & $5.57 \pm 0.99$ \\
\hline Valine & $5.80 \pm 0.25$ & $7.60 \pm 1.01$ \\
\hline Arginine & $9.68 \pm 0.89$ & $15.26 \pm 1.13$ \\
\hline Glycine & $2.48 \pm 0.16$ & $5.84 \pm 0.55$ \\
\hline \multicolumn{3}{|c|}{ Non-essential amino acids } \\
\hline Aspartate & $5.86 \pm 0.37$ & $17.32 \pm 2.08$ \\
\hline Alanine & $4.79 \pm 0.14$ & $7.75 \pm 0.92$ \\
\hline Glutamate & $18.56 \pm 1.28$ & $29.18 \pm 1.53$ \\
\hline Serine & $3.63 \pm 0.57$ & $8.89 \pm 0.66$ \\
\hline Total amino acids & $75.2 \pm 2.72$ & $144.1 \pm 1.89$ \\
\hline AAE & $42.36 \pm 2.28$ & $81.00 \pm 5.28$ \\
\hline AANE & $32.84 \pm 0.86$ & $63.14 \pm 2.49$ \\
\hline $\mathrm{AAE} / \mathrm{AANE}$ & $1.289 \pm 0.66$ & $1.283 \pm 0.93$ \\
\hline
\end{tabular}

\subsection{The Impact of Watermelon Rind and Sea Buckthorn Meal on Serum Hematological and Biochemical Parameters of Laying Hens}

The use of dietary watermelon rind and sea buckthorn meal on the hematological parameters (Table 4$)$ of laying hens showed no significant effect $(p>0.05)$ across groups. On the other hand, they had a significant impact $(p<0.05)$ on cholesterol and triglycerides in both E1 and E2 laying hens, compared with the hens from the C group (Table 5).

\subsection{Effects of Watermelon Rind and Sea Buckthorn Meal on Laying Hen Performance}

The impacts of watermelon rind and sea buckthorn meal feed on hens' performances are shown in Table 6. The experimental diets had no effects on the final bodyweight of the birds at the end of the trial. Average daily feed intake and viability were not influenced by the treatments. The feed conversion ratio was significantly $(p<0.05)$ impacted by feeding 
the E2 diet compared with the $\mathrm{C}$ and E1 diets. Egg weight was significantly impacted among the groups, as well as the egg weight classification.

Table 4. Hematological parameters of laying hens fed diets supplemented with watermelon rind and sea buckthorn meal.

\begin{tabular}{cccccc}
\hline Hematological Parameters & C & E1 & E2 & SEM & $p$-Value \\
\hline Hemoglobin, g/dL & 11.05 & 13.55 & 12.03 & 0.678 & 0.3471 \\
Mean corpuscular volume, fL & 101.43 & 101.10 & 100.48 & 0.624 & 0.6625 \\
Mean corpuscular hemoglobin, pg & 60.93 & 58.70 & 59.40 & 0.962 & 0.6823 \\
Hematocrit, \% & 18.33 & 23.58 & 20.25 & 1.269 & 0.2644 \\
White blood cell, \% & 86.70 & 83.26 & 84.21 & 10.367 & 0.3044 \\
Lymphocytes, \% & 68.15 & 73.83 & 64.40 & 3.604 & 0.6493 \\
Red blood cell, \% & 1.81 & 2.32 & 2.02 & 0.125 & 0.2732 \\
Eosinophil's granulocytes, \% & 14.40 & 11.57 & 19.90 & 2.835 & 0.2246 \\
Monocytes, \% & 5.75 & 4.77 & 6.07 & 0.188 & 0.4743 \\
Basophile's granulocytes, \% & 0.20 & 0.33 & 0.30 & 0.060 & 0.8558 \\
Platelet count & 23.75 & 25.25 & 24.25 & 0.960 & 0.3913 \\
\hline
\end{tabular}

C, control diet; E1, control diet supplemented with 1\% watermelon rind powder; E2, control diet supplemented with $2 \%$ sea buckthorn meal; $(n=6)$; SEM, standard error of the mean.

Table 5. Biochemical parameters of laying hens fed diets supplemented with watermelon rind and sea buckthorn meal.

\begin{tabular}{cccccc}
\hline Biochemical Parameters & C & E1 & E2 & SEM & $p$-Value \\
\hline Cholesterol, $\mathrm{mg} / \mathrm{dL}$ & $128.58^{\mathrm{a}}$ & $108.35^{\mathrm{b}}$ & $101.98^{\mathrm{b}}$ & 2.792 & 0.0255 \\
Triglycerides, $\mathrm{mg} / \mathrm{dL}$ & $1245.94^{\mathrm{a}}$ & $1018.17^{\mathrm{b}}$ & $1094.66^{\mathrm{b}}$ & 3.836 & 0.0439 \\
Glucose, $\mathrm{mg} / \mathrm{dL}$ & 230.12 & 228.07 & 202.20 & 6.237 & 0.2889 \\
Alanine aminotransferase, U/L & 7.70 & 6.25 & 5.48 & 0.570 & 0.1106 \\
Phosphorus, mg/dL & 3.60 & 4.72 & 3.97 & 0.261 & 0.2201 \\
Albumin, g/dL & 1.00 & 1.50 & 1.50 & 0.152 & 0.3811 \\
Magnesium, mg/dL & 2.45 & 2.64 & 2.64 & 0.107 & 0.7300 \\
Total protein, g/L & 1.52 & 1.92 & 1.65 & 0.089 & 0.1826 \\
\hline
\end{tabular}

C, control diet; E1, control diet supplemented with 1\% watermelon rind powder, E2, control diet supplemented with $2 \%$ sea buckthorn meal; $(n=6)$; SEM, standard error of the mean; ${ }^{\text {a,b }}$ Mean values within a row not sharing the same superscripts are significantly different.

Table 6. The effect of experimental diets on laying hen performance.

\begin{tabular}{cccccc}
\hline \multirow{2}{*}{ Parameters } & \multicolumn{3}{c}{ Experimental Diets } & \multirow{2}{*}{ SEM } & $p$-Value \\
\cline { 2 - 4 } & C & E1 & E2 & & \\
\hline Initial weight, g/layer & 1719.31 & 1720.69 & 1723.45 & 13.470 & 0.9921 \\
Final weight, g/layer & 1787.24 & 1785.00 & 1796.55 & 12.997 & 0.9301 \\
Average egg weight, g & $60.44^{\mathrm{a}}$ & $59.19^{\mathrm{c}}$ & $59.75^{\mathrm{b}}$ & 3.215 & 0.0001 \\
Average daily feed intake, g/day & 108.29 & 105.54 & 108.34 & 0.621 & 0.1085 \\
Feed conversion ratio, g feed/g egg & $1.83^{\mathrm{b}}$ & $1.82^{\mathrm{b}}$ & $1.91^{\mathrm{a}}$ & 0.015 & 0.0258 \\
Viability, \% & 100.00 & 100.00 & 100.00 & - & - \\
& Egg size classification, $\%$ & & & \\
\hline Small, (S < 53 g) & $0.74^{\mathrm{b}}$ & $2.72^{\mathrm{a}}$ & $0.99^{\mathrm{b}}$ & 5.271 & $<0.0001$ \\
Medium, (M 53-63 g) & $89.14^{\mathrm{c}}$ & $95.30^{\mathrm{a}}$ & $92.10^{\mathrm{b}}$ & 1.556 & $<0.0001$ \\
Large, (L 63-73 g) & $10.12^{\mathrm{a}}$ & $1.98^{\mathrm{c}}$ & $6.91^{\mathrm{b}}$ & 4.918 & $<0.0001$ \\
\hline
\end{tabular}

C, control diet; E1, control diet supplemented with 1\% watermelon rind powder; E2, control diet supplemented with $2 \%$ sea buckthorn meal; $(n=15)$; SEM, standard error of the mean. ${ }^{\mathrm{a}-\mathrm{c}}$ Mean values within a row not sharing the same superscripts are significantly different.

\subsection{Histology of the Duodenum and Jejunum}

The impact of dietary supplements on villus length and crypt depth determined in the duodenum are presented in Table 7. From the obtained results, we observed that villi length 
was significantly greater for E1 and E2 groups compared to the C group ( $p<0.001)$, while the depth of the crypts was significant $(p<0.05)$ just for the E2 group. Both morphometric measurements were significantly higher $(p<0.05)$ in the E2 group compared to the C group, while higher than the E1 group it was only the depth of crypts. Also, laying hens from the E2 group had significantly $(p<0.005)$ greater duodenum depth of crypt than those of the E1 group, both of them being higher than the $\mathrm{C}$ group.

Table 7. Measurements of the villi length and crypt depth for the duodenum and jejunum of experimental groups in comparison with the control group.

\begin{tabular}{cccccc}
\hline Item & C & E1 & E2 & SEM & $p$-Value \\
\hline \multicolumn{7}{c}{ Duodenum } \\
\hline Villi length $(\mu \mathrm{m})$ & $893.08^{\mathrm{c}}$ & $1292.82^{\mathrm{a}}$ & $1212.97^{\mathrm{b}}$ & 42.645 & $<0.0001$ \\
Crypt depth $(\mu \mathrm{m})$ & $154.81^{\mathrm{b}}$ & $174.60^{\mathrm{ab}}$ & $181.05^{\mathrm{a}}$ & 4.996 & $0.0699^{*}$ \\
Villi length: Crypt depth ratio $(\mathrm{V}: \mathrm{C})$ & $5.77^{\mathrm{b}}$ & $7.40^{\mathrm{a}}$ & $6.70^{\mathrm{ab}}$ & 0.267 & 0.0081 \\
\hline \multicolumn{7}{c}{ Jejunum $^{\text {jilli length }(\mu \mathrm{m})}$} & $871.54^{\mathrm{c}}$ & $1285.38^{\mathrm{a}}$ & $1127.93^{\mathrm{b}}$ & 187.698 & $<0.0001$ \\
\hline Crypt depth $(\mu \mathrm{m})$ & $133.25^{\mathrm{b}}$ & $250.70^{\mathrm{a}}$ & $159.32^{\mathrm{b}}$ & 15.247 & $<0.0001$ \\
Villi length:Crypt depth ratio $(\mathrm{V}: \mathrm{C})$ & $6.54^{\mathrm{a}}$ & $5.13^{\mathrm{b}}$ & $7.08^{\mathrm{a}}$ & 0.308 & 0.0108 \\
\hline
\end{tabular}

C, control diet; E1, control diet supplemented with $1 \%$ watermelon rind powder; E2, control diet supplemented with $2 \%$ sea buckthorn meal; $(n=6)$; SEM, standard error of the mean. * ANOVA value of $p$ was not significant; the superscripts were declared according to the Fischer test results; ${ }^{a-c}$ Mean values within a row not sharing the same superscripts are significantly different.

As in the case of the duodenum, villus length and crypt depth (Table 7) from the jejunum were significantly greater for E1 and E2 groups compared to the C group $(p<0.001)$. Both morphometric measurements showed significantly higher $(p<0.005)$ impact for the E1 and E2 groups compared to the C group. Villi length increased significantly $(p<0.005)$ in E1 and E2 when compared with $C$. The group supplemented with watermelon rind was also consistent, having the longest villi in the jejunum.

The intestinal morphometry appearances of the duodenum and jejunum are illustrated in Figures 1 and 2.

\subsection{Intestinal Enzymes Activities}

In the duodenum, the specific activity (SA) of E1 maltase increased by $167 \%$ and by $120 \%$ for E2 compared to the C group (Figure 3). In the jejunum, the same enzymatic activity decreased by $35 \%$ in the E1 group, while for E2, it was increased by $41 \%$ compared to the C group (Figure 4). Regarding the SA of invertase in the jejunum, no modification was observed in the duodenum of the E1 group, whereas, in the E2 group, it increased significantly $(p<0.05)$ by almost $212 \%$ compared to the $C$ group (Figure 3 ), which demonstrates that the basal diet supplemented with sea buckthorn (E2) determined a significant modification of invertase SA at the duodenum level compared to the $\mathrm{C}$ group. The results revealed a decrease of the SA of alpha-amylase in the E1 and E2 groups for the duodenum intestinal part compared to the $C$ group but without significant effect (Figure 3), while in the jejunum segment of the intestine, the E2 group was significantly $(p<0.05)$ lower compared with the $\mathrm{C}$ group. The SA of trypsin in the duodenum was significantly $(p<0.01)$ impacted by the E1 and E2 experimental diets compared with the C diet. Furthermore, the enzymatic SA of alpha-amylase in the jejunum was significantly lower in E1 and E2 $(p<0.01)$ compared with the $C$ group, whereas the trypsin enzymatic SA in the jejunum segment of laying hens was without modifications $(p>0.05)$, even if it tended to be lower in the E2 group. 




Figure 1. Effect of watermelon rind and sea buckthorn supplementation diet on the duodenum morphology of laying hens. The basal diet served as the control and the experimental groups were supplemented with watermelon rind (E1) and sea buckthorn (E2); sce, simple columnar epithelium; $\mathrm{lp}$, lamina propria; cr, crypt; mm, muscularis mucosa. Bb, brush border; H\&E (Hematoxylin and Eosin), Barr-20 $\mu \mathrm{m}$. 

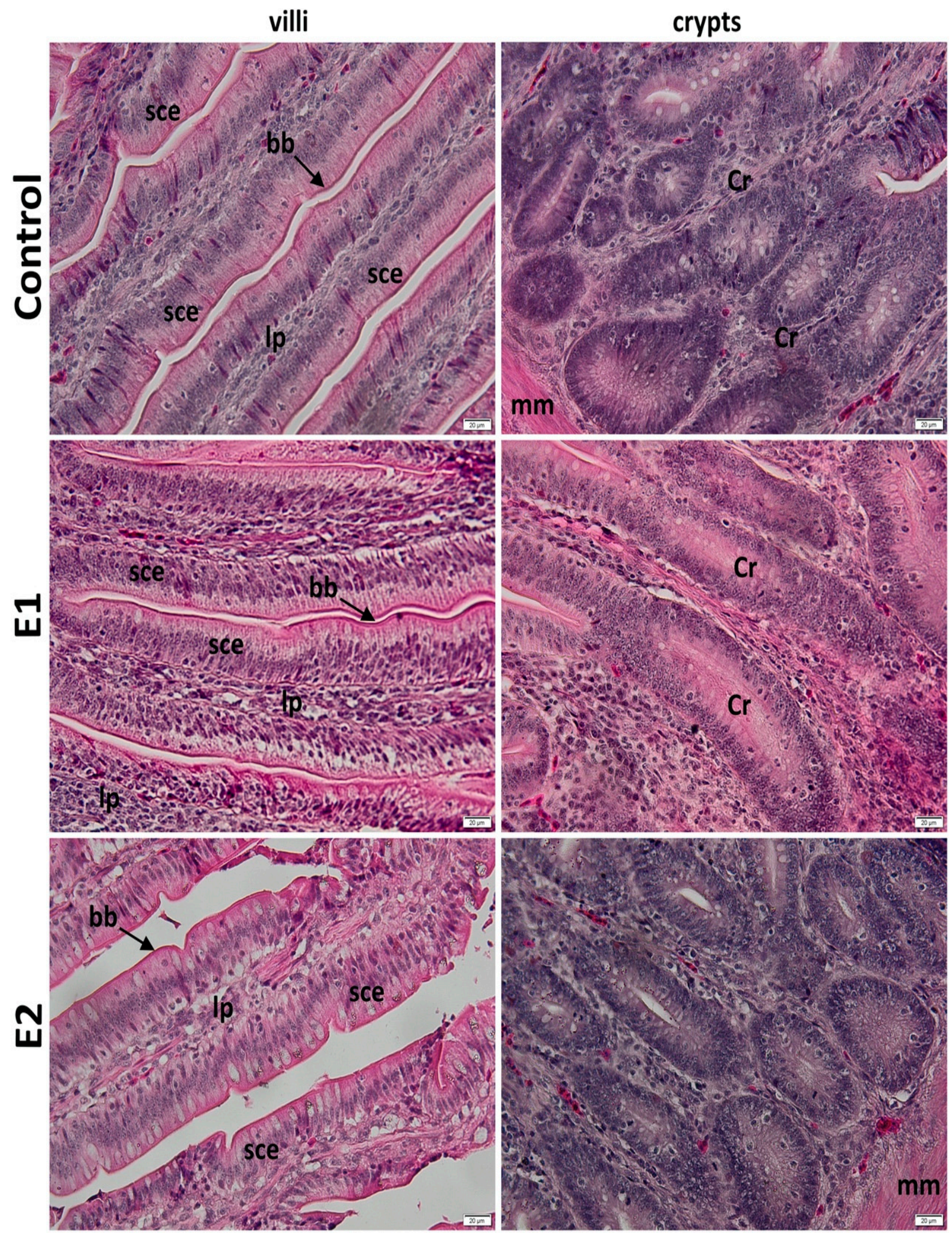

Figure 2. Effect of watermelon rind and sea buckthorn supplementation diet on the jejunal morphology of laying hens. The basal diet served as the control and the experimental groups were supplemented with watermelon rind (E1) and sea buckthorn (E2); sce, simple columnar epithelium; $\mathrm{lp}$, lamina propria; cr, crypt; $\mathrm{mm}$, muscularis mucosa. Bb, brush border; H\&E (Hematoxylin and Eosin), Barr-20 $\mu \mathrm{m}$. 

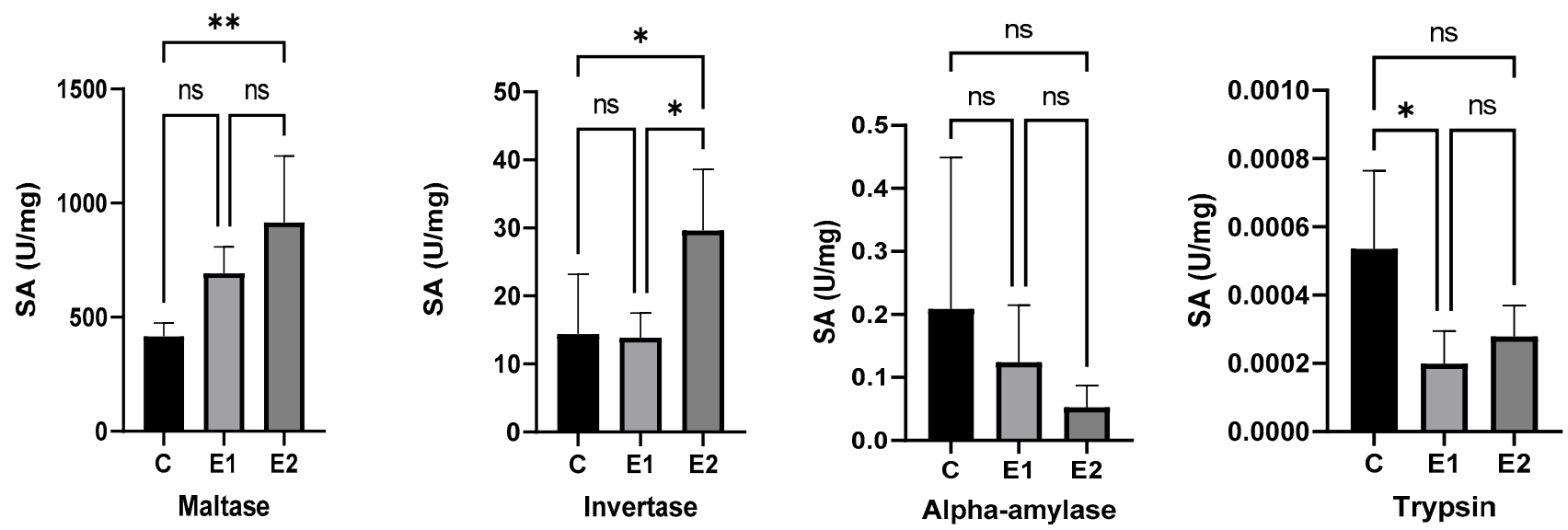

Figure 3. Effect of watermelon rind (E1) and sea buckthorn meal (E2) supplementation on the enzymatic specific activity (SA) of maltase and invertase, expressed as $\mathrm{U} / \mathrm{mg}$ protein, from the duodenum mucosa. Significant at ${ }^{*} p \leq 0.05$; significant at ${ }^{* *} p \leq 0.01 ;(n=6) ; \mathrm{n}$ : number of replicates; ns: none significant.
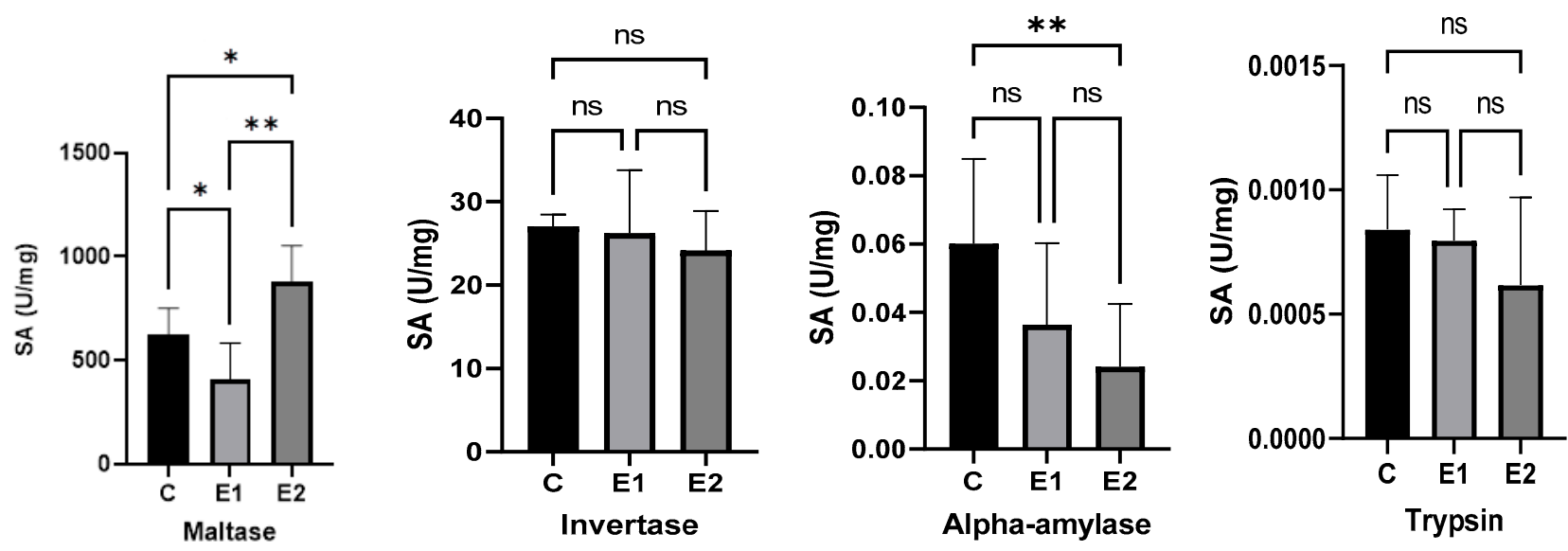

Figure 4. Effect of watermelon rind (E1) and sea buckthorn meal (E2) supplementation on the enzymatic specific activity (SA) of alpha-amylase and trypsin, expressed as $\mathrm{U} / \mathrm{mg}$ protein, from the jejunum mucosa. Significant at ${ }^{*} p \leq 0.05$; significant at ${ }^{* *} p \leq 0.01 ;(n=6) ; n$ : number of replicates; ns: none significant.

\subsection{Intestinal Microbiota}

The relative abundance of Firmicutes phylum was significantly $(p<0.01)$ higher in both the E1 and E2 groups compared to the $C$ group (Figure 5). Feeding laying hens the E1 and E2 diets led to a significant $(p<0.05)$ decrease in abundance of Bacteroidetes phylum. For the relative abundance of Bacteroidetes, the E2 group was significantly lower $(p<0.05)$ than both the $C$ and E1 groups. Furthermore, the experimental diets aimed to trigger beneficial modifications of the microbiota by enrichment of bacteria with probiotic potential while diminishing the abundance of potentially pathogenic bacteria such as Enterobacteriaceae. The abundance of Lactobacillus spp. in isolated cecal samples from laying hens fed with different dietary formulas was significantly impacted in both experimental groups compared with the $C$ group. 

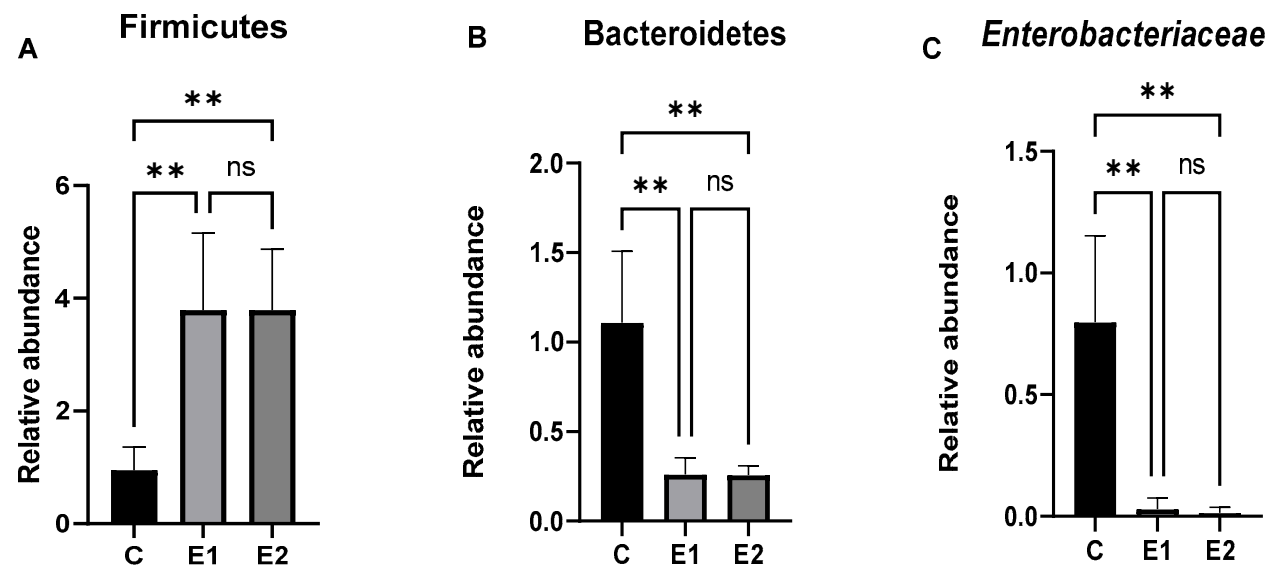

Lactobacillus spp.

Figure 5. The relative abundance of Firmicutes (A), Bacteroidetes (B), Enterobacteriaceae (C), and Lactobacillus spp. (D), as determined by qRT-PCR; Eubacteria $16 \mathrm{~S}$ was used for normalization; Each column represents the relative average abundance among the treatments, $(n=6),{ }^{*} p<0.05,{ }^{* *} p<0.01$, (unpaired $t$-test). ns: none significant.

3.7. Correlation between Performance Parameters, Digestibility of Nutrients, Crude Fiber Content, Intestinal Microbiota, and Histology of the Duodenum and Jejunum of the Laying Hens

The Pearson's correlation was calculated between performances (ADFI and BW), digestibility of crude protein (dCP), $\mathrm{CF}$, intestinal morphometry (VL, CD and V:C ratio), intestinal enzymes activities (maltase, invertase, amylase, and trypsin), and the relative abundance of Firmicutes, Enterobacteriaceae, Lactobacilli, and Bacteroidetes in the intestinal microbiota. The correlation results are presented in Figure 6. Positive correlations were found between $\mathrm{dCP}(r=0.992, p<0.05)$ and $\mathrm{CF}, \mathrm{dCP}(r=0.999, p<0.05)$ and maltase (duodenum), BW ( $r=0.988, p<0.05)$ and invertase (duodenum), CF, VL (jejunum) $(r=0.998, p<0.05)$ and the VL:CD ratio (duodenum), CD (duodenum) $(r=0.994, p<0.05)$ and Lactobacilli, invertase (jejunum) $(r=0.997, p<0.05)$ with amylase (jejunum), amylase (jejunum) $(r=0.991, p<0.05)$ and amylase (duodenum), Firmicutes $(r=0.992, p<0.05)$ and Lactobacilli, and Enterobacteriaceae $(r=1.000, p<0.01)$ and Bacteroidetes. In contrast, amylase (duodenum) is negatively correlated with $\mathrm{dCP}(r=-1.000, p<0.01)$ and amylase (duodenum) $(r=-1.000, p<0.01)$, dCP with amylase (jejunum) $(r=-1.000, p<0.01), \mathrm{CF}$ $(r=-0.991, p<0.05)$ with invertase (jejunum), amylase (duodenum) $(r=-0.999, p<0.05)$ with VL (duodenum), amylase (jejunum) $(r=-0.995, p<0.05)$ with CD (duodenum), maltase (duodenum) $(r=-1.000, p<0.01 ; r=-0.993, p<0.05)$ ) with amylase (duodenum) and amylase jejunum, Firmicutes $(r=-1.000, p<0.01)$ with Enterobacteriaceae and Bacteroidetes, Enterobacteriaceae $(r=-0.993, p<0.05)$ with Lactobacilli, and Lactobacilli $(r=-0.992, p<0.05)$ with Bacteroidetes. 


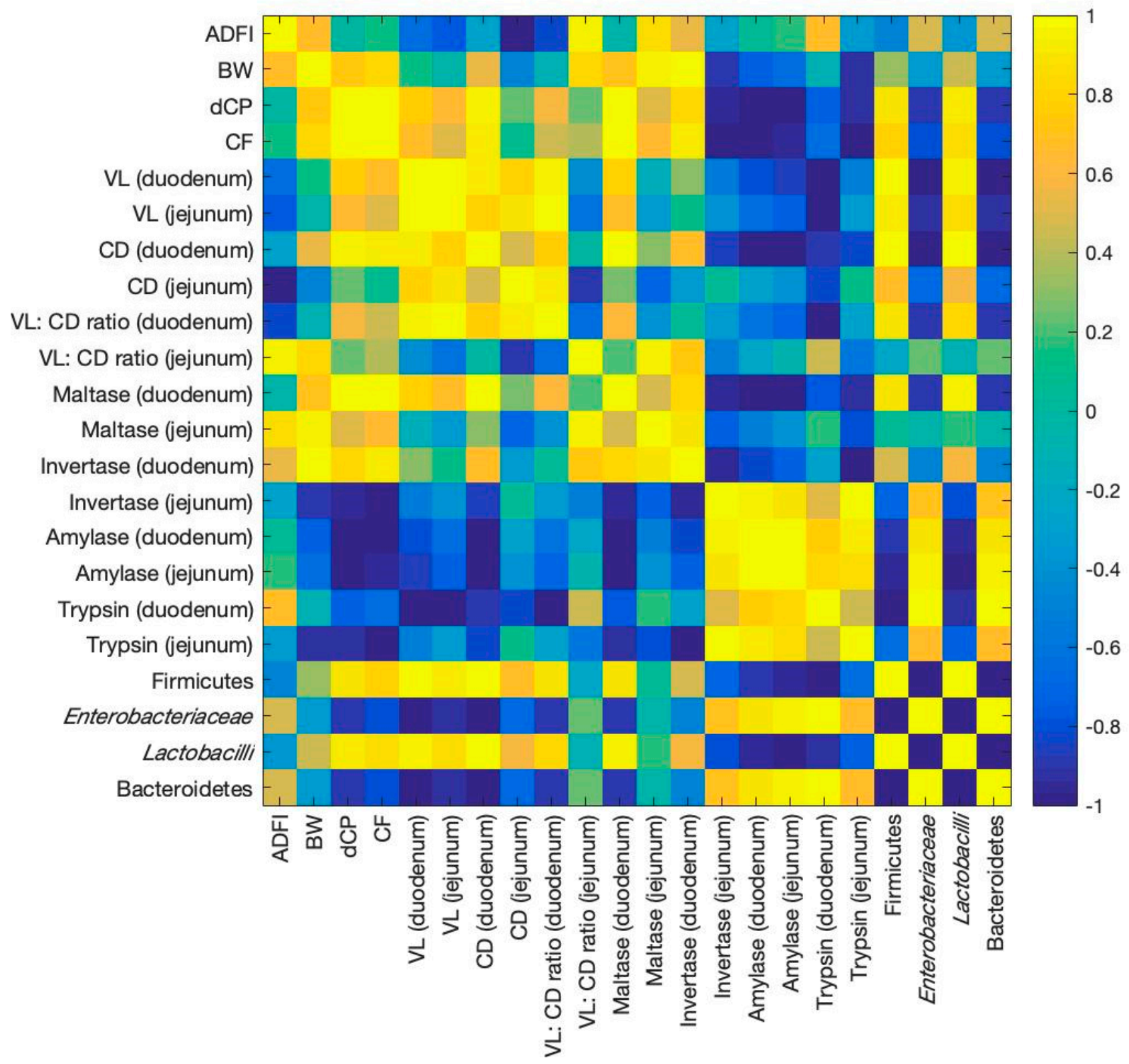

Figure 6. A heatmap showing Pearson's correlations between multiple parameters, predominant genera in the duodenum, jejunum, and intestinal morphology. Yellow indicates a positive correlation; blue indicates a negative correlation. Abbreviations: VL, villous length; CD, crypt depth; VL: CD, villous length: crypt depth.

\section{Discussion}

The $\mathrm{CP}$ contents determined in watermelon rind and sea buckthorn meal were $95.6 \mathrm{~g} / \mathrm{kg}$ and $145.1 \mathrm{~g} / \mathrm{kg}$, respectively, which were lower than those reported by Hoque and Iqbal [21], but higher than the values reported by Al-Sayed and Ahmed [23]. Similarly, variable differences in the chemical composition of sea buckthorn meal, ranging from $11.44 \%$ to $18.30 \%$ or $20.87 \%$ were reported by others [34-36]. The CF content was $168.4 \mathrm{~g} / \mathrm{kg}$ for watermelon rind and $205.2 \mathrm{~g} / \mathrm{kg}$ for sea buckthorn meal; this result shows a significant difference between the two supplements. Different values are reported in the literature as well for $\mathrm{CF}$ in watermelon ranging from $1.57 \%$ to $7.8 \%$, and $14.50 \%$ [37-39]. For the sea buckthorn meal, the CF values reported are higher than in the watermelon rind, which is in line with our results $[35,40]$. The concentration of AA determined in our dietary feed ingredients showed variable differences when compared with those found in the 
literature [41]. The AAs are very important because they play important roles in regulating the properties and functions of intestinal epithelial cells, digestion of food, absorption of nutrients, and protection of the body from microbial infections [42].

In the current study, hematological parameters were not impacted by dietary ingredients. These results for all the parameters fall within the normal range values established for birds [43]. The nutritional state of the animal is shown by normal hematological levels. As a result, the normal values found in this study imply that the birds' nutritional needs are being met. It also suggests that the birds' immune systems are adequate. However, from the biochemical parameters, the cholesterol and triglyceride concentrations in the serum of the E1 and E2 groups were significantly impacted. This effect is probably caused by the dietary ingredients used, which present a hypocholesterolemic effect, resulting in lower cholesterol and triglyceride concentrations. Another explanation is that watermelon rind and sea buckthorn have indirect inhibitory effects exerted at the levels of reductase, which is a key enzyme in cholesterol biosynthesis. This result suggests that the studied dietary ingredients were capable of reducing serum cholesterol and triglycerides; therefore, they could be helping to reduce the deposition of cholesterol in the eggs. This finding agreed with the results reported by others [44-46], who observed decreased cholesterol and triglycerides in birds fed with plants and herbs as dietary feed additives.

The beneficial impact of these by-products on biochemical parameters is negatively correlated with the production performances of laying hens. The dietary supplements tested were not significant contributors to the BW or ADFI of laying hens, but the FCR ( $g$ feed/g egg) was significantly impacted in the E2 diet compared with the E1 and C diets. We assume that this effect is produced by the high crude fiber content present in the sea buckthorn meal. The significant alteration of FCR was also previously reported when sea buckthorn was used [47-49] without effect on ADFI. Furthermore, the E1 and E2 diets significantly impacted average egg weight. This effect was caused by the fact that both the $\mathrm{E} 1$ and $\mathrm{E} 2$ groups had significantly fewer large eggs compared with the $\mathrm{C}$ group, while the E1 had a significantly higher $(p<0.001)$ percentage of medium-weight eggs. In line with our results, we reported that Moringa olifera leaves, up to $15 \%$ in laying hens' diets, significantly decreased egg weight while increasing the FCR [50-52]. The observed decrease in egg weight and increased FCR in the current study could be associated with the presence of some anti-nutritional factors present in these feed additives that have resulted in better bird health with decreased production, as was speculated by some authors [53,54]. From a physiological point of view, first, hens can suffer as egg size increases, and second, larger eggs tend to have thinner shells because there is a limited amount of calcium carbonate a hen can access from her diet and bones. This will cause wastage of eggs as they crack, as well as financial loss to the egg producer. From an economic point of view, because both the watermelon rind and the sea buckthorn can be obtained for free from the processing factories to minimize waste pollution, this could lower the price of feed by replacing some of the main ingredients (corn, soy). However, obtaining watermelon rind involves a higher consumption of energy resources for the drying process. This can lead to additional costs. Although we believe that the recycling and reuse of this by-product in poultry feed is an attractive and nutrient-rich source, an assessment of the costs involved in the large-scale production of this feed is needed. Regarding egg weight, as shown in the EC Regulation [55], all class A eggs, which include S, M, L, and XL eggs, are sold in kg, not based on their individual weights. With respect to consumer preferences, some studies showed that while some consumers prefer larger eggs, others prefer medium eggs, but healthier ones from healthy animals [56,57]. However, it is difficult to explain why the addition of sea buckthorn meal caused higher FCR and lower egg weight. This aspect needs further research.

The present results show that the light microscopic examination parameters (villus length and crypt depth) in both intestinal segments (duodenum and jejunum) were normal, which means they had similar nutrient absorption in the duodenum and jejunum. Villus length and crypt depth are important indicators for intestinal health and highlight the 
absorptive capacity of the mucous membrane [58,59], which further stimulates the selective population of intestinal microbiota. This achievement suggests that dietary watermelon and sea buckthorn meal could increase the intestinal surface area and, consequently, enhance the absorption of the available feed nutrients. Maintaining or increasing villus length provides a good surface area for the available nutrient absorption. For normal poultry growth, body development and physiological functions come from diet nutrients, which are further digested and absorbed, for which the gastrointestinal tract plays an important role. For this reason, intestinal integrity plays a crucial role in animal growth development by promoting nutrient digestion and absorption $[60,61]$. Some histological studies have shown that the intestinal villi lengths in chickens $[62,63]$ are well recognized as being affected by dietary components, as previous studies reported that intestinal villi were shorter and narrower in chickens fed unbalanced diets compared with those fed a nutritionally wellbalanced diet $[64,65]$. In our study, the dietary supplements used affected the structure of the small intestine in laying hens, characterized in part by a lengthening of the total luminal villus absorptive area, which further resulted in satisfactory digestive enzyme action and higher transport of nutrients at the villus surface. In addition, the changes that appear in intestinal morphology may influence nutrient metabolization and animal performance because longer intestinal villi are correlated with improved gut health $[66,67]$. Based on these microscopic results, dietary watermelon rind and sea buckthorn could offer a competitive advantage over the control diet, resulting in the improved intestinal health status of the laying hens. Data reported in the literature from when laying hens were fed with different dietary supplements concur with our results [68-70]. However, it was reported that the lengthening of villi may increase the total luminal villus absorptive area, but, in addition, the changes that appear in intestinal morphology may influence nutrient metabolization and animal performance [71]. Data reported in the literature when laying hens were fed different dietary supplements concur with our results, but to our knowledge, there are no studies available on the effect of dietary watermelon rind on the intestinal traits of laying hens. The maltase activity significantly increased in both duodenum and jejunum in the $\mathrm{E} 2$ compared to the $\mathrm{C}$ group, while the activity of alpha-amylase significantly decreased in the jejunum of both experimental groups compared to the control. Also, the sea buckthorn added in the E2 diet determined an increase of invertase specific activity at the duodenum level. These improvements produced by the use of dietary watermelon rind and sea buckthorn have further implications in maintaining normal intestinal digestion and the absorption functions of nutrients. The activities of intestinal digestive enzymes, including $\alpha$-amylase, trypsin, maltase, and invertase, are considered important parameters for feed efficiency and the performance of animals, playing a crucial role in nutrient digestion [72]. Amylase, protease, and lipase are important digestive enzymes, secreted from the pancreas, distributed and activated in the duodenum and jejunum small intestine sections, for nutrient digestion and absorption. However, trypsin and maltase activity has been previously observed to decrease in aging laying hens [4]. Recently, similar results were achieved [31] when hens were fed a diet including $0.5 \%$ bilberry leaves and $1 \%$ walnut leaves. So far, no information is available regarding the effect of watermelon peel and sea buckthorn meal on the digestive enzyme activities of laying hens.

Animal diet is a crucial modulator of gut microbiota composition [73]. Hence, the constituents of various dietary formulations warrant special attention in the regulation of the intestinal microflora ecosystem. In our study, the diets supplemented with watermelon rind (E1) and sea buckthorn meal (E2) triggered beneficial modifications in the microbiota by enrichment of bacteria with probiotic potential (Lactobacillus spp.), while diminishing the abundance of potentially pathogenic bacteria (Enterobacteriaceae). We noted that there was significant diversity in the relative abundance of bacterial populations among different parts of the intestinal microbiota (duodenum and jejunum). This effect is normal because each part of the intestine develops its unique microbial profile, as others have reported $[74,75]$. Although much research has been done regarding the effects of natural additives on the intestinal microbiota of poultry, detailed information about the impact of 
these dietary feed additives on chicken microbiota is still lacking. Previous studies showed that dietary supplementation with dietary plants as feed additives [76-78] alters the microbiota population in poultry mainly by increasing the abundance of Lactobacilli. These modifications in the gastrointestinal tract populations are caused by polyphenol's presence in the dietary ingredients. Polyphenols can inhibit the growth of certain species (i.e., Bacteroides) while favoring other species (i.e., Firmicutes). The mechanism of polyphenol action in the intestinal microbiota was largely studied by others [79]. The microbial transformations differ depending on the type of polyphenols structures. Therefore, members of different subgroups and categories are metabolized through different pathways and result in differential effects on the gut microbiota population [80,81]. Therefore, these modifications in the intestinal segments of laying hens represent an improvement in intestinal health generated by the impact of watermelon rind and sea buckthorn meal supplementation as feed additives that can help intestinal tissue by decreasing the pathogens present in the gastrointestinal tract of birds.

The Pearson's correlation showed a positive effect between $\mathrm{CF}$ and amylase, $\mathrm{dCP}$ and maltase, and Firmicutes and Lactobacilli in the duodenum and jejunum, while a negative correlation was observed between $\mathrm{CF}$ and VL, dCP and amylase, and Firmicutes and Lactobacilli with Enterobacteriaceae and Bacteroidetes. Corresponding to the alterations in cecal microbiota, Pearson's correlation analysis further identified that genera Bacteroides, Firmicutes, Lactobacillus, and Enterobacteriaceae exhibited markedly positive or negative correlations with nutrient digestibility and/or ileal morphology, supporting that dietary watermelon rind and sea buckthorn supplementation mediated intestinal functions by targeting the gut microbiota. In the current study, the abundance of Lactobacillus was significantly increased by dietary ingredients and elicited positive correlations with the ileal villus length to crypt depth ratio, whereas the abundance of Bacteroides was significantly reduced following watermelon rind and sea buckthorn addition. Thus, Lactobacillus and Bacteroides might play essential roles in modulating intestinal morphology and nutrient digestibility in laying hens.

\section{Conclusions}

The current results suggest that a supplementation level of $20 \mathrm{~g} / \mathrm{kg}$ of sea buckthorn had a detrimental effect on FCR and egg weight, indicating a lower supplementation level could be suitable for their use in layers' diets. The health status was significantly improved by decreasing the cholesterol and triglyceride concentration in the serum. The present results highlight that dietary watermelon rind and sea buckthorn meal had a beneficial impact on laying hens' intestinal morphology, leading to the development of bacteria with probiotic potential while reducing the abundance of pathogenic bacteria.

However, further research is needed concerning the dietary ingredients studied, their relationship with health status, gut microbiota, and production performances, together with their economic impact.

Author Contributions: Conceptualization, T.D.P., P.A.V. and M.S.; data curation, T.D.P., P.A.V., M.S. and A.C.; formal analysis, T.D.P., P.A.V., M.S., A.C., I.V., S.N.V. and A.H.; funding acquisition, T.D.P.; investigation, T.D.P., P.A.V., M.S., A.C., I.V., S.N.V. and A.H.; methodology, A.C., I.V., S.N.V. and A.H.; project administration, T.D.P.; software, T.D.P., P.A.V., M.S., S.N.V. and A.H.; supervision, T.D.P.; visualization, T.D.P., P.A.V. and M.S.; writing-original draft, T.D.P., P.A.V., M.S., A.C., I.V., S.N.V. and A.H.; and writing-review \& editing, T.D.P., P.A.V. and M.S. All authors have read and agreed to the published version of the manuscript.

Funding: This research was funded by the Romanian Ministry of Research, Innovation and Digitization through project component 8 PCCDI 043 PC3.

Institutional Review Board Statement: The study was conducted according to the guidelines of the Declaration of Helsinki and approved by the Ethics Commission of the National ResearchDevelopment Institute for Animal Biology and Nutrition (Protocol No. 5148/10.08.2018), according to Directive 2010/63/EU on the protection of animals used for scientific purposes. 
Informed Consent Statement: Not applicable.

Data Availability Statement: All data is contained within the article.

Acknowledgments: This research was supported by funds from the 8 PCCDI 043 PC 3 and from the National Research Development Project Projects to Finance Excellence (PFE)-8/2021 granted by the Romanian Ministry of Research, Innovation and Digitalization.

Conflicts of Interest: The authors declare no conflict of interest. The funders had no role in the design of the study, in the collection, analyses, or interpretation of data, in the writing of the manuscript, or in the decision to publish the results.

\section{References}

1. Alagawany, M.; Elnesr, S.S.; Farag, M.R.; Tiwari, R.; Yatoo, M.I.; Karthik, K.; Michalak, I.; Dhama, K. Nutritional significance of amino acids, vitamins and minerals as nutraceuticals in poultry production and health-A comprehensive review. Vet. Quart. 2021, 41, 1-29. [CrossRef] [PubMed]

2. Smith, J.A. Experiences with drug-free broiler production. Poult. Sci. 2011, 90, 2670-2678. [CrossRef] [PubMed]

3. Morgan, N.K. Managing gut health without reliance on antimicrobials in poultry. Anim. Prod. Sci. 2017, 57, 2270-2279. [CrossRef]

4. Gu, Y.F.; Chen, Y.P.; Jin, R.; Wang, C.; Wen, C.; Zhou, Y.M. A comparison of intestinal integrity, digestive function, and egg quality in laying hens with different ages. Poult. Sci. 2021, 100, 100949. [CrossRef]

5. Apajalahti, J. Structure and dietary modulation of intestinal microbial communities. In Proceedings of the 2nd Mid-Atlantic Nutrition Conference, Timonium, MD, USA, 24-25 March 2004.

6. Siro, I.; Kapolna, E.; Kapolna, B.; Lugasi, A. Functional food. Product development, marketing and consumer acceptance-A review. Appetite 2008, 51, 456-467. [CrossRef]

7. Kuzyšinová, K.; Mudroňová, D.; Toporčák, J.; Nemcová, R.; Molnár, L.; Ma'ari, A.; Vaníková, S.; Kožár, M. Testing of inhibition activity of essential oils against Paenibacillus larvae-The causative agent of American foulbrood. Acta Vet. Brno 2014, 83, 9-12. [CrossRef]

8. Yadav, A.S.; Kolluri, G.; Gopi, M.; Karthik, K.; Singh, Y. Exploring alternatives to antibiotics as health-promoting agents in poultry-A review. J. Exp. Biol. 2016, 4, 368-383. [CrossRef]

9. Ravindran, R.; Jaiswal, A.K. Exploitation of food industry waste for high-value products. Trends Biotechnol. 2016, 34, 58-69. [CrossRef]

10. Saracila, M.; Criste, R.D.; Panaite, T.D.; Vlaicu, P.A.; Tabuc, C.; Turcu, R.P.; Olteanu, M. Artemisia annua as phytogenic feed additive in the diet of broilers (14-35 days) reared under heat stress ( $\left.32{ }^{\circ} \mathrm{C}\right)$. Braz. J. Poult. Sci. 2018, 20, 825-832. [CrossRef]

11. Panaite, T.D.; Criste, R.D.; Vlaicu, P.A.; Saracila, M.; Tabuc, C.; Olteanu, M.; Turcu, R.P.; Buleandră, M. Influence of artemisia annua on broiler performance and intestinal microflora. Braz. J. Poult. Sci. 2019, 21, 1-9. [CrossRef]

12. Vlaicu, P.A.; Untea, A.E.; Panaite, T.D.; Turcu, R.P. Effect of dietary orange and grapefruit peel on growth performance, health status, meat quality and intestinal microflora of broiler chickens. Ital. J. Anim. Sci. 2020, 19, 1394-1405. [CrossRef]

13. Yang, Z.; Liao, S.F. Physiological effects of dietary amino acids on gut health and functions of swine. Front. Vet. Sci. 2019, 6, 169. [CrossRef]

14. Yamaguchi, M. World Vegetables: Principles, Production and Nutritive Values; AVI Publishing Corporation: Westport, CT, USA, 2006.

15. Hoque, M.M.; Iqbal, A. Drying of watermelon rind and development of cakes from rind powder. Int. J. Nov. Res. Life Sci. 2015, 2, 14-21.

16. Perkins-Veazie, P.; Collins, J.K. Flesh quality and lycopene stability of fresh-cut watermelon. Postharvest Biol. Technol. 2004, 31, 159-166. [CrossRef]

17. Al-Sayed, H.M.; Ahmed, A.R. Utilization of watermelon rinds and sharlyn melon peels as a natural source of dietary fiber and antioxidants in cake. Ann. Agric. Sci. 2013, 58, 83-95. [CrossRef]

18. Mohan, A.; Shanmugam, S. Comparison of the nutritional, physico-chemical and anti-nutrient properties of freeze and hot air dried watermelon (Citrullus Lanatus) rind. Biosci. Biotechnol. Res. 2016, 13, 1113-1119. [CrossRef]

19. Suryakumar, G.; Gupta, A. Medicinal and therapeutic potential of Sea buckthorn (Hippophae rhamnoides L.). J. Ethnopharmac. 2011, 138, 268-278. [CrossRef]

20. Gao, X.; Ohlander, M.; Jeppsson, N.; Bjork, L.; Trajkovski, V. Changes in antioxidant effects and their relationship to phytonutrients in fruits of sea buckthorn (Hippophae rhamnoides L.) during maturation. J. Agric. Food Chem. 2000, 48, 1485-1490. [CrossRef]

21. Zeb, A. Chemical and nutritional constituents of sea buckthorn juice. Pak. J. Nutr. 2004, 3, 99-106.

22. Oomah, B.D. Sea Buckthorn Lipids. In Sea Buckthorn (Hippophae rhamnoides): Production and Utilization; Li, T.S.C., Beveridge, T., Eds.; NRC Research Press: Ottawa, ON, USA, 2003; pp. 51-68.

23. Bal, L.M.; Meda, V.; Naik, S.N.; Santosh, S. Sea buckthorn berries: A potential source of valuable nutrients for nutraceuticals and cosmoceuticals. Food Res. Int. 2011, 44, 1718-1727. [CrossRef]

24. Lee, H.I.; Kim, M.S.; Lee, K.M.; Park, S.K.; Seo, K.I.; Kim, H.J.; Kim, M.J.; Choi, M.S.; Lee, M.K. Anti-visceral obesity and antioxidant effects of powdered sea buckthorn (Hippophae rhamnoides L.) leaf tea in diet-induced obese mice. Food Chem. Toxic. 2011, 49, 2370-2376. [CrossRef] [PubMed] 
25. Janssen, W.M.M.A. European Table of Energy Values for Poultry Feedstuffs; Wageningen: Beekbergen, The Netherlands, 1898.

26. Boisen, S.; Fernandez, J.A. Prediction of the apparent ileal digestibility of protein and amino acids in feedstuffs and feed mixtures for pigs by in vitro analyses. Anim. Feed Sci. Technol. 1995, 51, 29-43. [CrossRef]

27. National Research Council. Nutrient Requirements of Poultry, 9th ed.; National Academic Press: Washington, DC, USA, 1994.

28. AOAC. Association of Official Analytical Chemists; Official Methods of Analysis: Gaithersburg, MD, USA, 1990.

29. Falade, O.S.; Otemuyiwa, I.O.; Adekunle, A.S.; Adewusi, S.A.; Oluwasefunmi, O. Nutrient composition of watermelon (Citrullis lanatus (Thunb.) Matsum. And Nakai) and egusi melon (Citrullus colocynthis (L.) Schrad.) seeds. Agric. Conspec. Sci. 2020, 85, 43-49.

30. Varzaru, I.; Untea, A.E.; Martura, T.; Olteanu, M.; Panaite, T.D.; Schitea, M.; Van, I. Development and validation of an RP-HPLC method for methionine, cystine and lysine separation and determination in corn samples. Rev. Chim. 2013, 64, 673-679.

31. Popescu, R.G.; Voicu, S.N.; Gradisteanu Pircalabioru, G.; Ciceu, A.; Gharbia, S.; Hermenean, A.; Georgescu, S.E.; Panaite, T.D.; Dinischiotu, A. Effects of dietary inclusion of bilberry and walnut leaves powder on the digestive performances and health of Tetra SL laying hens. Animals 2020, 10, 823. [CrossRef] [PubMed]

32. Bernfeld, P. Amylases: Alpha and beta methods. Enzymology 1995, 1, 149-158.

33. Hummel, B.C.W. A modified spectrophotometric determination of chymotrypsin, trypsin and thrombin. Can. J. Biochem. Physiol. 1995, 37, 1393-1399. [CrossRef]

34. Vlaicu, P.A.; Panaite, T.D.; Turcu, R.P. Enriching laying hens eggs by feeding diets with different fatty acid composition and antioxidants. Sci. Rep. 2021, 11, 1-12. [CrossRef]

35. Biswas, A.; Bharti, V.K.; Acharya, S.; Pawar, D.D.; Singh, S.B. Sea buckthorn: New feed opportunity for poultry in cold arid Ladakh region of India. World Poult. Sci. J. 2010, 66, 707-714. [CrossRef]

36. Ben-Mahmoud, Z.; Mohamed, M.S.; Bláha, J.; Lukešová, D.; Kunc, P. The effect of sea buckthorn (Hippophae rhamnoides L.) residues in compound feeds on the performance and skin color of broilers. Indian J. Anim. Res. 2014, 48, 548-555. [CrossRef]

37. Fila, W.A.; Itam, E.H.; Johnson, J.T.; Odey, M.O.; Effiong, E.E. Comparative proximate compositions of watermelon Citrullus lanatus, squash Cucurbita pepo'l and rambutan Nephelium lappaceum. Int. J. Sci. Technol. 2013, 2, 81-88.

38. Gwana, A.M.; Bako, M.M.; Bagudu, B.Y.; Sadiq, A.B.; Abdullahi, M.M. Determinations of phytochemical, vitamin, mineral and proximate compositions of varieties of watermelon seeds cultivated in Borno State, North-Eastern Nigeria. Int. J. Nutr. Food Sci. 2014, 3, 238-245. [CrossRef]

39. Nguyen, L.T.; Han, G.; Yang, H.; Ikeda, H.; Eltahan, H.M.; Vishwajit, S.C.; Mitsuhiro, F. Dried watermelon rind mash diet increases plasma l-citrulline level in chicks. J. Poult. Sci. 2019, 56, 65-70. [CrossRef]

40. Panaite, T.D.; Criste, R.D.; Ropota, M.; Criste, V.; Vasile, G.; Olteanu, M.; Mitoi, M.; Turcu, R.P.; Vlaicu, A. Determination of the feeding value of food industry by-products. Sci. Pap.-Anim. Sci. Ser. 2016, 66, 106-111.

41. Egbuonu, A.C.C. Comparative assessment of some mineral, amino acid and vitamin compositions of watermelon (Citrullus lanatus) rind and seed. Asian J. Biochem. 2015, 10, 230-236. [CrossRef]

42. Kong, S.; Zhang, Y.H.; Zhang, W. Regulation of intestinal epithelial cells properties and functions by amino acids. BioMed Res. Int. 2018, 2018. [CrossRef]

43. Bolu, S.A.; Sola-Ojo, F.E.; Olorunsanya, O.A.; Adekola, O.G. Effect of graded levels of melon Seed (Citrullus lanatus) cake on the performance, carcass evaluation and blood parameters of broiler chicken. Anim. Nutr. Feed Technol. 2011, 11, 63-70.

44. Albokhadaim, I. Haematological and some biochemical values of indigenous chickens in Al-Ahsa, Saudi Arabia during summer season. Asian J. Poult. Sci. 2012, 6, 138-145. [CrossRef]

45. Vlaicu, P.A.; Panaite, T.D.; Olteanu, M.; Ropota, M.; Criste, V.; Vasile, G.; Grosu, I. Production parameters, carcass development and blood parameters of the broiler chick fed diets which include rapeseed, flax, grape and buckthorn meals. Sci. Pap. Anim. Sci. Biotechnol. 2017, 50, 37-45.

46. Sharma, A.; Shukla, P.K.; Bhattacharyya, A.; Kumar, U.; Roy, D.; Yadav, B.; Prakash, A. Effect of dietary supplementation of sea buckthorn and giloe leaf meal on the body weight gain, feed conversion ratio, biochemical attributes, and meat composition of turkey poults. Vet. World 2018, 11, 93-98. [CrossRef]

47. Pathak, G.P.; Sharma, N.; Mane, B.G.; Sharma, D.; Krofa, D.; Khurana, S.K. Effect of Sea buckthorn (Hippophae rhamnoides)-leaves, pulp and oil on growth performance, carcass characteristics and meat quality of broilers chicken. J. Poult. Sci. Technol. 2015, 3 , 20-23.

48. Saracila, M.; Panaite, T.D.; Untea, A.; Varzaru, I.; Dragotoiu, D.; Criste, R.D. Use of the dietary sea buckthorn meal as phytoaditive in heat-stressed broiler. Sci. Pap. Ser. D Anim. Sci. 2020, 63, 83-91.

49. Nour, V.; Panaite, T.D.; Corbu, A.R.; Ropota, M.; Turcu, R.P. Nutritional and bioactive compounds in dried sea-buckthorn pomace. Erwerbs-Obstbau 2021, 63, 91-98. [CrossRef]

50. Nobakht, A. The possibility of using watermelon waste in laying hens diets. Iran. J. App. Anim. Sci. 2015, 5, 459-462.

51. Santin, E.; Maiorka, A.; Macari, M.; Grecco, M.; Sanchez, J.C.; Okada, T.M.; Myasaka, A.M. Performance and intestinal mucosa development of broiler chickens fed diets containing Saccharomyces cerevisiae cell wall. J. Appl. Poult. Res. 2001, 10, 236-244. [CrossRef]

52. Lu, W.; Wang, J.; Zhang, H.J.; Wu, S.G.; Qi, G.H. Evaluation of Moringa oleifera leaf in laying hens: Effects on laying performance, egg quality, plasma biochemistry and organ histopathological indices. Ital. J. Anim. Sci. 2016, 15, 658-665. [CrossRef] 
53. Abou-Elezz, F.M.K.; Sarmiento-Franco, L.; Santos-Ricalde, R.; Solorio-Sanchez, F. Nutritional effects of dietary inclusion of Leucaena leucocephala and Moringa oleifera leaf meal on Rhode Island Red hens' performance. Cuba. J. Agric. Sci. 2011, 45, 163-169.

54. Kakengi, A.M.V.; Kaijage, J.T.; Sarwatt, S.V.; Mutayoba, S.K.; Shem, M.N.; Fujihara, T. Effect of Moringa oleifera leaf meal as a substitute for sunflower seed meal on performance of laying hens in Tanzania. Bone 2007, 1, 446.

55. Commission Implementing Regulation (EU) 2017/1185 of 20 April 2017 Laying down Rules for the Application of Regulations (EU) No 1307/2013 and (EU) No 1308/2013 of the European Parliament and of the Council as Regards Notifications to the Commission of Information and Documents and Amending and Repealing Several Commission Regulations. Available online: https:/ / eur-lex.europa.eu/legal-content/EN/TXT/?uri=CELEX\%3A32017R1185 (accessed on 24 January 2022).

56. Bejaei, M.; Wiseman, K.; Cheng, K.M. Developing logistic regression models using purchase attributes and demographics to predict the probability of purchases of regular and specialty eggs. Br. Poult. Sci. 2015, 56, 425-435. [CrossRef]

57. Heng, Y.; Peterson, H.H.; Li, X. Consumer attitudes toward farm-animal welfare: The case of laying hens. J. Agric. Resour. Econ. 2013, 38, 418-434.

58. Prakatur, I.; Miskulin, M.; Pavic, M.; Marjanovic, K.; Blazicevic, V.; Miskulin, I.; Domacinovic, M. Intestinal Morphology in Broiler Chickens Supplemented with Propolis and Bee Pollen. Animals 2019, 9, 301. [CrossRef]

59. Zhaxi, Y.; Meng, X.; Wang, W.; Wang, L.; He, Z.; Zhang, H.; Pu, W. Duan-Nai-An, A Yeast Probiotic, Improves Intestinal Mucosa Integrity and Immune Function in Weaned Piglets. Sci. Rep. 2020, 10, 4556. [CrossRef]

60. Fang, C.L.; Sun, H.; Wu, J.; Niu, H.H.; Feng, J. Effects of sodium butyrate on growth performance, haematological and immunological characteristics of weanling piglets. J. Anim. Physio Anim. Nutr. 2014, 98, 680-685. [CrossRef]

61. Qin, L.; Ji, W.; Wang, J.; Li, B.; Hu, J.; Wu, X. Effects of dietary supplementation with yeast glycoprotein on growth performance, intestinal mucosal morphology, immune response and colonic microbiota in weaned piglets. Food Funct. 2019, 10, $2359-2371$. [CrossRef]

62. Ege, G.; Bozkurt, M.; Koçer, B.; Tüzün, A.E.; Uygun, M.; Alkan, G. Influence of feed particle size and feed form on productive performance, egg quality, gastrointestinal tract traits, digestive enzymes, intestinal morphology, and nutrient digestibility of laying hens reared in enriched cages. Poult. Sci. 2019, 98, 3787-3801. [CrossRef]

63. Incharoen, T.; Yamauchi, K. Production performance, egg quality and intestinal histology in laying hens fed dietary dried fermented ginger. Int. J. Poult. Sci. 2009, 8, 1078-1085. [CrossRef]

64. Maneewan, B.; Yamauchi, K.E. Effects of semi-purified pellet diet on the chicken intestinal villus histology. J. Poult. Sci. 2003, 40, 254-266. [CrossRef]

65. Maneewan, B.; Yamauchi, K. Recovery of duodenal villi and cells in chickens refed protein, carbohydrate and fat. Br. Poult. Sci. 2005, 46, 415-423. [CrossRef]

66. Van Nevel, C.J.; Decuypere, J.A.; Dierick, N.A.; Molly, K. Incorporation of galactomannans in the diet of newly weaned piglets: Effect on bacteriological and some morphological characteristics of the small intestine. Arch. Anim. Nutr. 2005, 59, 123-138. [CrossRef]

67. Baurhoo, B.; Phillip, L.; Ruiz-Feria, C.A. Effects of purified lignin and mannan oligosaccharides on intestinal integrity and microbial populations in the ceca and litter of broiler chickens. Poult. Sci. 2007, 86, 1070-1078. [CrossRef]

68. Lokaewmanee, K.; Yamauchi, K.; Okuda, N. Effects of dietary red pepper on egg yolk colour and histological intestinal morphology in laying hens. J. Anim. Physiol. Anim. Nutr. 2013, 97, 986-995. [CrossRef] [PubMed]

69. Adibmoradi, M.; Navidshad, B.; Seifdavati, J.; Royan, M. Effect of dietary garlic meal on histological structure of small intestine in broiler chickens. Poult. Sci. 2006, 43, 378-383. [CrossRef]

70. Abdullah, A.A.; Mahmoud, K.Z.; Nusairat, B.M.; Qudsieh, R.I. Small intestinal histology, production parameters, and meat quality as influenced by dietary supplementation of garlic (Allium sativum) in broiler chicks. Ital. J. Anim. Sci. 2010, 9, 419-424. [CrossRef]

71. Tufarelli, V.; Desantis, S.; Zizza, S.; Laudadio, V. Performance, gut morphology and carcass characteristics of fattening rabbits as affected by particle size of pelleted diets. Arch. Anim. Nutr. 2010, 64, 373-382. [CrossRef]

72. Takahama, U.; Hirota, S. Interactions of flavonoids with $\alpha$-amylase and starch slowing down its digestion. Food Funct. 2018, 9 , 677-687. [CrossRef]

73. Leeming, E.R.; Johnson, A.J.; Spector, T.D.; Le Roy, C.I. Effect of diet on the gut microbiota: Rethinking intervention duration. Nutrients 2019, 11, 2862. [CrossRef]

74. Amit-Romach, E.; Sklan, D.; Uni, Z. Microflora ecology of the chicken intestine using 16S ribosomal DNA primers. Poult. Sci. 2004, 83, 1093-1098. [CrossRef]

75. Richards, J.D.; Gong, J.; De Lange, C.F.M. The gastrointestinal microbiota and its role in monogastric nutrition and health with an emphasis on pigs: Current understanding, possible modulations, and new technologies for ecological studies. Can. J. Anim. Sci. 2005, 85, 421-435. [CrossRef]

76. Vlaicu, P.A.; Panaite, T.D.; Turcu, R.P.; Tabuc, C. Dietary Origanum vulgare supplements for broilers. Rom. Biotechnol. Lett. 2020, 25, 1922-1929. [CrossRef]

77. Panaite, T.D.; Saracila, M.; Papuc, C.P.; Predescu, C.N.; Soica, C. Influence of dietary supplementation of salix alba bark on performance, oxidative stress parameters in liver and gut microflora of broilers. Animals 2020, 10, 958. [CrossRef]

78. Ren, H.; Vahjen, W.; Dadi, T.; Saliu, E.-M.; Boroojeni, F.G.; Zentek, J. Synergistic Effects of Probiotics and Phytobiotics on the Intestinal Microbiota in Young Broiler Chicken. Microorganisms 2019, 7, 684. [CrossRef] 
79. Cardona, F.; Andrés-Lacueva, C.; Tulipani, S.; Tinahones, F.J.; Queipo-Ortuño, M.I. Benefits of polyphenols on gut microbiota and implications in human health. J. Nutr. Biochem. 2013, 24, 1415-1422. [CrossRef]

80. Iqbal, Y.; Cottrell, J.J.; Suleria, H.A.R.; Dunshea, F.R. Gut Microbiota-Polyphenol Interactions in Chicken: A Review. Animals 2020, 10, 1391. [CrossRef]

81. Saracila, M.; Panaite, T.D.; Papuc, C.P.; Criste, R.D. Heat Stress in Broiler Chickens and the Effect of Dietary Polyphenols, with Special Reference to Willow (Salix spp.) Bark Supplements-A Review. Antioxidants 2021, 10, 686. [CrossRef] 